\title{
Influence of Social Media on Consumer Behavior Among University Students in Nairobi City County, Kenya
}

\author{
DANIEL NDIEMA MUNYOKI J.M, PHD \\ UNIVERSITY OF NAIROBI, SCHOOL OF BUSINESS, P.O BOX 30197, GPO, Nairobi, Kenya
}

\begin{abstract}
This study sought to establish the influence of social media on consumer behavior amongst university students in Nairobi city county, Kenya. The general objective of the study was to establish the influence of social media on consumer behavior amongst university students in Nairobi city county. A Cross-sectional research design was used in this study. The sample frame consisted of university students within Nairobi city county. Convenience sampling technique was used and the sample size was arrived at using Krejcie and Morgan's (1970) Table of sample sizes. 384 questionnaires were printed and distributed to collect primary data. 307 respondents returned the questionnaires which were administered and collected physically. The data was interpreted using the Statistical Package for Social Sciences (SPSS). The results of the study were represented in the form of Tables only. The study found out that there was a positive correlation between social media and consumer behavior of the respondents. Both internal and external stimuli are key to recognize the need to purchase a product. The study further found that Social media provides information on problems being faced by consumers. Friends and peers share comments, and likes towards product brands. It also provides an avenue for soliciting and relaying customer feedback. The study concluded that indeed social media has an enormous influence on consumer behavior amongst university students within Nairobi county.
\end{abstract}

Keywords: influence, consumer behavior, social media, University students, Decision making

DOI: $10.7176 / \mathrm{EJBM} / 12-21-06$

Publication date:July $31^{\text {st }} 2020$

\section{INTRODUCTION}

Kaplan and Heinlein (2010), define social media as a group of internet-based appliances allowing fabrication and generation of operator-generated substance by providing forums for sharing the very contents without the need of coming into contact with the handlers. This aspect necessitates a greater part of marketing by organizations that at most lead to increased sales, growth of market shares, and revenue. Sometimes companies resort to hiring bloggers who push their product attributes to consumers. This media is cheap but more efficient to use as it reaches a wider market within a short time at a minimal cost. This media is rapidly evolving and as such more changes are expected in the future. It is quickly penetrating the market due to improved internet connections, affordable internet rates, and the advent of smartphones amongst the population. Globally, there are over three billion users of social media with an annual average increase of $13 \%$ ((Social. (2017). Hoot suite. (2018)).

Kotler and Keller (2006), define consumer behavior as a choice-making act either for persons, factions and organizations on how to acquire, use, and dispose of merchandises and thoughts. It majorly relies on one's ability to spend available resources concerning the required products. It is influenced by various factors like technology, culture, demographic and psychological changes. The product attributes are said to be accepted or rejected by consumer's likes and dislike posted on social media. Product users normally trust user-generated reviews and recommendations as opposed to traditional media (Mangolds \& Faulds, 2009).

University students are mainly young adults and thus have a high frequency of accessing and using social media sites before making consumption decisions. They are more enlightened thus demand value for every coin spent. They like interactions and quick feedback. Despite the rapid growth and penetration of social media, other internet events have emerged for consumers like blogging, chatting and, gaming (Boyd \& Ellison, 2007). It has become a platform for entertainment and networking. Therefore, it was prudent for this research to establish a deeper understanding if students consume products as a result of using social media and how they interact on virtual environment. The general objective was to ascertain the effects of social media on buyer behavior amongst university learners in Nairobi city county. Other goals were: To determine the influence of social media on diverse phases of the customer decision-making process and To ascertain factors that contribute to using social media amongst university students.

\section{LITERATURE REVIEW}

This study was supported by two theories: Howard Sheth model and The Black Box model. Howard and Sheth (1969) developed the Theory of Buyer Behavior by use of Howard Sheth model. The model postulated a logic that there must be stimuli (inputs) that will be transformed to have purchases (outputs). In between the stimuli and output were various variables. There are three levels of decision making. The first is extensive problem solving where consumers have little or no basic information about a technical product brand. The consumers also have 
minimal product experience. The second stage is limited problem solving where consumers have little knowledge of the products they wish to purchase. They are likely to do a brand comparison. The last stage is habitual response behavior where consumers have strong inclinations towards their favorite brands. It majorly entails everyday consumer products. The inputs are composed of information sources majorly from the consumer's environment like significance, symbolic, and social stimuli.

Kotler (1967), published the black box stimulus-response theory of consumer behavior. The consumer's mind was thus referred to as a black box that required stimulation to achieve the desired response. The theory suggested that an external stimulus must trigger the black box before any buying decision is made. The stimuli can be promotion methods, availability of products, advertisements, lifestyle, social status among others. After the detection of the stimuli, a transformation happens in the mind to give an output. The response has only two alternatives: either purchase or no purchase. If one is satisfied, then a purchase is made else no purchase.

Empiricists have in the past tried to study the influence of social media on consumer behavior. Chen (2014), studied the influence of social media on consumer behavior in China and found out that there was a greater relationship between cordiality, reliance, promptness, and openness. This paper solitary converged on definite aspects like friendliness, dependence, speediness, and openness. Ayda and Wei, (2012) scrutinized the influence of electronic social systems on consumer buying decisions: an argument of foodstuff vendors in Sweden. It focused on the stages of clients during online shopping and purchases. It revealed that the variables showed positive connection due to convenience, containing interactive attributes, and are where consumers pass their schedule mostly on Facebook.

Oyetunde, (2017) explored the power of Facebooking and societal media on academic performance among Nigerian students. He focused on three Nigerian universities and submitted his findings to the University of South Africa. He found out a negative correlation between Facebook usage and academic performance. Pather, (2014) examined issues shaping purchaser choice making activity in Africa (Kenya, Uganda, Tanzania, Nigeria, and Ghana). It was revealed that a positive macroeconomic setting both in east and west Africa that leads to low and extreme end shoppers. The elements traverse through the countries to inspire spending were related.

Mwaisaka, (2017) investigated the inspiration of social media on the consumer decision-making process in cosmetic industries in Nairobi found that there was a positive relationship between the variables. The perceived intentions for using cosmetics and social media. Also the factors that influence men to start and continue using cosmetics needs were not revealed. Mwangi, (2017) studied the influence of social marketing on consumer behavior in Nyeri town. She found out that there was a fair correlation between the variables and that consumption choices were less swayed by label identification.

Mugenda and Mugenda, (2003) noted that a conceptual framework is a hypothesized model identifying the concepts under study and their relationships. It is a diagrammatic representation that shows the inter-relationships between various variables in the study as shown in Figure 2.1. The independent variable is social media having attributes like accessibility and reliability whereas the dependent variable is customer satisfaction comprising of consumer decisions. Social media should be reliable that is it should be effective and efficient. 


\section{Independent variables}

\section{Accessibility of social media}

+ Product information

posts

+ Internet connectivity rates and speed

+ Frequency of using social media

$+\quad$ Mo des of accessing social media

\section{Reliability of social media}

+ Effectiveness /Efficiency of social media

$+\quad$ Likes, shares and comments

$+\quad$ Chats and messaging

+ Quality of feedback

\author{
Dependent variables
}

\author{
Consumer behavior \\ + Decision making \\ + Customer \\ satisfaction/dissatisfaction
}

Figure 2.1: Conceptual Framework (Source: Author, 2019)

\section{RESEARCH METHODOLOGY}

This study was done using a Cross-sectional research design which entailed the use of differentiated groups of people with different variables though they shared similar characteristics like educational level and social status. The target population were all university learners within Nairobi city county estimated at 169,000 (CUE,2016). The sample size was 384 respondents copied on Krejcie and Morgan (1970) table of sample sizes. A convenience sampling technique was used to pick the respondents. Primary data was collected using a questionnaire and all the analysis was done using statistical package for social sciences (SPSS) and presented using tables and figures.

\section{FINDINGS}

A total of 384 questionnaires were distributed to the respondents but only 307 were returned which was an $80 \%$ response rate. The overall reliability coefficient was 0.675 and hence the findings were reliable for further use or research. The majority of the respondents were between age 18-35 years at $98.7 \%$. and were pursuing either certificate, diploma, or degree at an overall rate of $97.7 \%$. The respondents were required to state their favorite social media sites and the results were as shown in table 1. 


\subsection{Table 1: Media used}

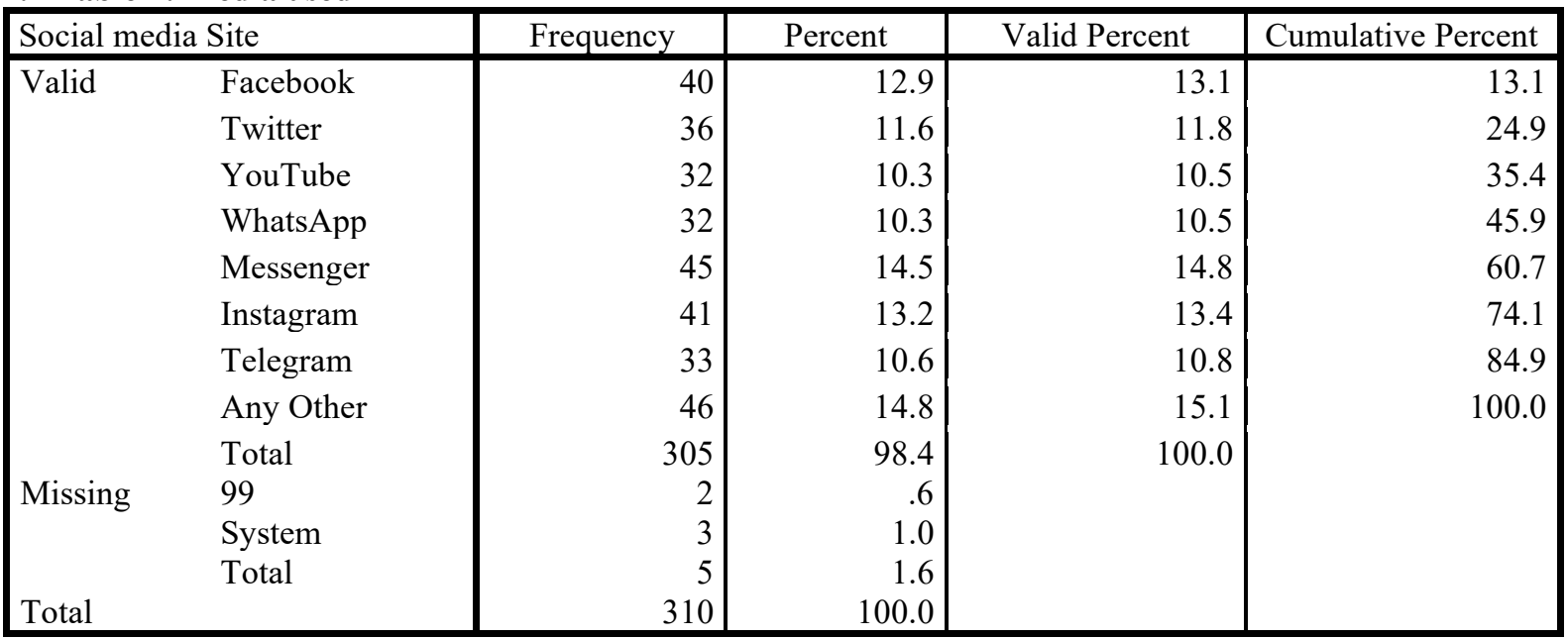

As indicated in Table 1 Facebook is still the most favorable social media site although there is a close correlation between various sites. The use of multiple sites emerges as the best technique since information posted in each though related was slightly different.

The respondents were asked to indicate the total hours they spend on social media a day; the findings are shown in Table 2.

\subsection{Table 2: Time spent on social media}

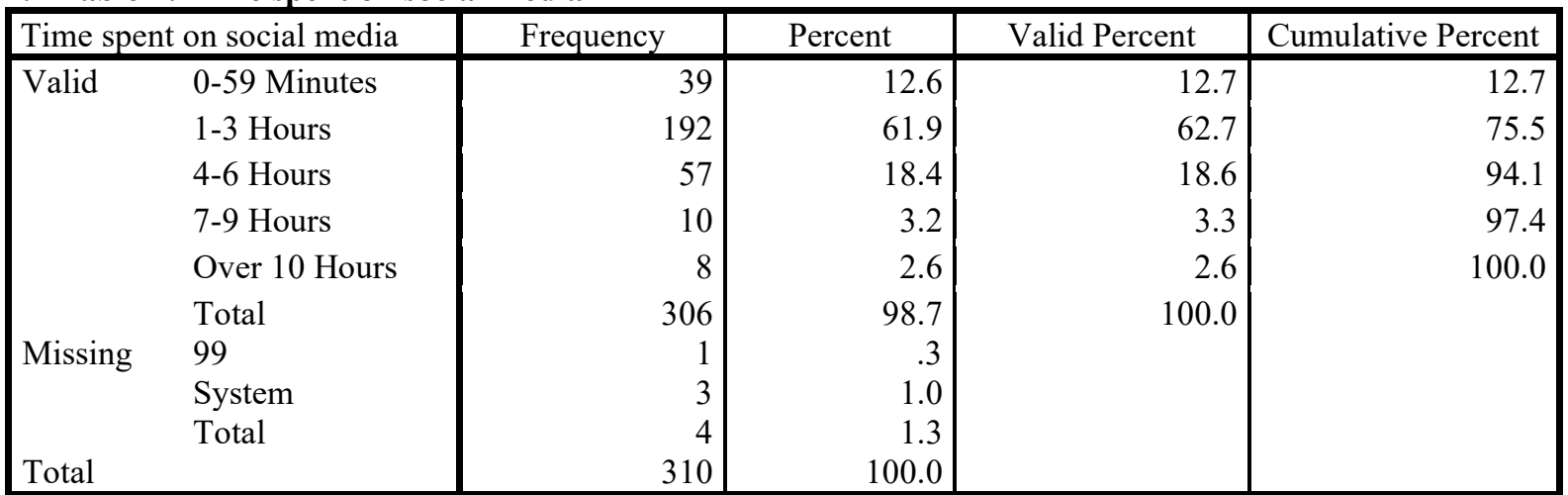

As shown in Table 2, an overall $94.1 \%$ spent at least six hours a day on various social media sites and were majorly pursuing either certificate or diploma courses and thus were full-time students who relied on institutions free $\mathrm{Wi}-\mathrm{Fi}$ as opposed to using of data bundles.

The respondents were asked to indicate if the rates and speed of internet connectivity motivated frequent usage of social media influenced their consumption behavior. The findings are shown in Table 3.

\subsection{Table 3: Influence of Rates and Speed of Internet Connectivity.}

\begin{tabular}{|c|c|c|c|c|c|}
\hline \multicolumn{2}{|c|}{$\begin{array}{l}\text { Extent of agreement on influence of speed and rates o } \\
\text { internet connectivity }\end{array}$} & Frequency & Percent & $\begin{array}{c}\text { Valid } \\
\text { Percent }\end{array}$ & $\begin{array}{l}\text { Cumulative } \\
\text { Percent }\end{array}$ \\
\hline \multirow[t]{6}{*}{ Valid } & Very large extent & 135 & 43.5 & 44.1 & 44.1 \\
\hline & Large extent & 115 & 37.1 & 37.6 & 81.7 \\
\hline & Moderate extent & 38 & 12.3 & 12.4 & 94.1 \\
\hline & Less extent & 12 & 3.9 & 3.9 & 98.0 \\
\hline & No extent & 6 & 1.9 & 2.0 & 100.0 \\
\hline & Total & 306 & 98.7 & 100.0 & \\
\hline Missing & System & 4 & 1.3 & & \\
\hline Total & & 310 & 100.0 & & \\
\hline
\end{tabular}

As shown in table 3, there was an overall 94.1\% level of agreement that the rates and speed of internet connectivity played a major role in influencing consumer behavior amongst university students. The faster the internet speed, the more likely use of social media amongst students.

The respondents were required to rate their levels of agreement on whether Product information posted on 
social media is always true and factual, $91.5 \%$ agreed that product information posted on social media is rated as true and factual and thus can be used in decision making towards the use of certain products as shown in table four.

4.4 Table 4: Truth and Facts of Posted Product Information

\begin{tabular}{|c|c|c|c|c|c|}
\hline \multicolumn{2}{|c|}{$\begin{array}{l}\text { Extent of agreement to whether posted product information } \\
\text { on social media was true and factual }\end{array}$} & Frequency & Percent & $\begin{array}{c}\text { Valid } \\
\text { Percent }\end{array}$ & $\begin{array}{l}\text { Cumulative } \\
\text { Percent }\end{array}$ \\
\hline \multirow[t]{6}{*}{ Valid } & Very large extent & 95 & 30.6 & 30.9 & 30.9 \\
\hline & Large extent & 76 & 24.5 & 24.8 & 55.7 \\
\hline & Moderate extent & 59 & 19.0 & 19.2 & 74.9 \\
\hline & Less extent & 51 & 16.5 & 16.6 & 91.5 \\
\hline & No extent & 26 & 8.4 & 8.5 & 100.0 \\
\hline & Total & 307 & 99.0 & 100.0 & \\
\hline Missing & System & 3 & 1.0 & & \\
\hline Total & & 310 & 100.0 & & \\
\hline
\end{tabular}

The findings showed an overall $91.5 \%$ agreed that the product information posted on social media was true and factual and thus could be reliable to influence consumer behavior.

The respondents were also required to note their levels of agreement to how easy it was to receive and retrieve information via social media and the findings were as shown in table five.

\subsection{Table 5: Ease of Searching Information Via Social Media.}

\begin{tabular}{|c|c|c|c|c|c|}
\hline \multicolumn{2}{|c|}{$\begin{array}{l}\text { Extent of agreement to ease of searching information via } \\
\text { social media }\end{array}$} & \multirow{2}{*}{$\frac{\text { Frequency }}{64}$} & \multirow{2}{*}{$\frac{\text { Percent }}{20.6}$} & \multirow{2}{*}{ 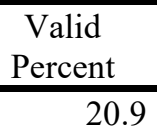 } & \multirow{2}{*}{$\begin{array}{r}\begin{array}{l}\text { Cumulative } \\
\text { Percent }\end{array} \\
20.9\end{array}$} \\
\hline Valid & Very large extent & & & & \\
\hline & Large extent & 56 & 18.1 & 18.3 & 39.2 \\
\hline & Moderate extent & 67 & 21.6 & 21.9 & 61.1 \\
\hline & Less extent & 56 & 18.1 & 18.3 & 79.4 \\
\hline & No extent & 63 & 20.3 & 20.6 & 100.0 \\
\hline & Total & 306 & 98.7 & 100.0 & \\
\hline \multirow[t]{3}{*}{ Missing } & 99 & 1 & .3 & & \\
\hline & System & 3 & 1.0 & & \\
\hline & Total & 4 & 1.3 & & \\
\hline Total & & 310 & 100.0 & & \\
\hline
\end{tabular}

From the findings in table five, overall $79.4 \%$ agreed that the search of information on social media was way much easier as opposed to traditional media. The respondents could easily get product information through smartphones at their own comfort.

On the other hand, the respondents were required to rate their level of agreement on whether pop up messages and advertisements were a nuisance to them, the findings were as shown in table six.

\subsection{Table 6: Negative Influence of Pop Up Advertisements Towards Products}

\begin{tabular}{|c|c|c|c|c|c|}
\hline \multicolumn{2}{|c|}{$\begin{array}{l}\text { Extent of agreement on negative influence of pop up } \\
\text { messages and advertisements }\end{array}$} & Frequency & Percent & $\begin{array}{c}\text { Valid } \\
\text { Percent }\end{array}$ & $\begin{array}{l}\text { Cumulative } \\
\text { Percent }\end{array}$ \\
\hline \multirow[t]{6}{*}{ Valid } & Very large extent & 104 & 33.5 & 34.0 & 34.0 \\
\hline & Large extent & 115 & 37.1 & 37.6 & 71.6 \\
\hline & Moderate extent & 52 & 16.8 & 17.0 & 88.6 \\
\hline & Less extent & 22 & 7.1 & 7.2 & 95.8 \\
\hline & No extent & 13 & 4.2 & 4.2 & 100.0 \\
\hline & Total & 306 & 98.7 & 100.0 & \\
\hline Missing & System & 4 & 1.3 & & \\
\hline Total & & 310 & 100.0 & & \\
\hline
\end{tabular}

As shown in table 6, Pop up messages and advertisements were found as unpleasant and irritating at $95.8 \%$ levels of agreement and influences negative attitude towards a brand or product that might as well negatively influence consumer behavior of a given product. They were thus viewed as a nuisance.

Furthermore, the respondents were required to rate the attractiveness and up to date of social media advertisements and the findings were as shown in table seven. 
4.7 Table 7: Attractiveness and Up to Date of Social Media Advertisements

\begin{tabular}{|ll|r|r|r|r|}
\hline $\begin{array}{l}\text { Extent of agreement on attractiveness of social media } \\
\text { advertisements }\end{array}$ & Frequency & Percent & $\begin{array}{c}\text { Valid } \\
\text { Percent }\end{array}$ & $\begin{array}{c}\text { Cumulative } \\
\text { Percent }\end{array}$ \\
\hline Valid & Very large extent & 134 & 43.2 & 43.8 & 43.8 \\
& Large extent & 97 & 31.3 & 31.7 & 75.5 \\
& Moderate extent & 48 & 15.5 & 15.7 & 91.2 \\
& Less extent & 17 & 5.5 & 5.6 & 96.7 \\
& No extent & 10 & 3.2 & 3.3 & 100.0 \\
Missing & Total & 306 & 98.7 & 100.0 & \\
Total & System & 4 & 1.3 & & \\
\hline
\end{tabular}

From table 7, the advertisements propelled through social media were found to be attractive and up to date with an overall $96.7 \%$ ability to influence one to purchase a product or use a service. Their graphics and mode of demonstrations had a possibility of influencing one to consume a product. The findings greatly agree with Kotler and Keller, (2009) who noted that buyers conduct an active information search in order to learn about the product before making or not making a purchase. The advertisements are regarded to be of high credibility having detailed information of how, where, and when to find the products as opposed to traditional broadcast media.

There was need for respondents to note whether their next purchase was likely to be influenced by social media recommendations and the findings were as shown in table eight.

4.8 Table 8 shows the influence of social media recommendation on next product purchase.

\begin{tabular}{|c|c|c|c|c|c|}
\hline \multicolumn{2}{|c|}{$\begin{array}{l}\text { Extent of agreement on whether next purchase relies on } \\
\text { social media recommendations }\end{array}$} & Frequency & Percent & $\begin{array}{c}\text { Valid } \\
\text { Percent }\end{array}$ & $\begin{array}{l}\text { Cumulative } \\
\text { Percent }\end{array}$ \\
\hline \multirow[t]{6}{*}{ Valid } & Very large extent & 103 & 33.2 & 33.9 & 33.9 \\
\hline & Large extent & 99 & 31.9 & 32.6 & 66.4 \\
\hline & Moderate extent & 57 & 18.4 & 18.8 & 85.2 \\
\hline & Less extent & 28 & 9.0 & 9.2 & 94.4 \\
\hline & No extent & 17 & 5.5 & 5.6 & 100.0 \\
\hline & Total & 304 & 98.1 & 100.0 & \\
\hline \multirow[t]{3}{*}{ Missing } & 99 & 2 & .6 & & \\
\hline & System & 4 & 1.3 & & \\
\hline & Total & 6 & 1.9 & & \\
\hline Total & & 310 & 100.0 & & \\
\hline
\end{tabular}

Table 8 shows that the next purchase of similar products will largely depend on recommendations and user's responses done via social media at a $94.4 \%$ agreement level. The expressions of respondents are well done by the use of emoji, stickers, and animations. The period after purchasing a product normally involves product ownership and usage after the transfer of ownership which usually results in either one being satisfied or not (Wang, 2012). The feedback can be seen from a point of customer's complaints or word of mouth transmissions. Satisfaction majorly translates to loyalty and as such voluntary brand ambassadors. Social media usually provide an interactive forum for product users to easily voice their concerns and opinions about product attributes, (Campbell and Goodstein, 2001). There was an insignificant influence on the use of social media and consumer behavior by attributes like age, gender, and educational levels.

When age, gender, and educational status was analyzed to see their effects on consumer behavior, the results showed that there was a less significant influence on one's consumption behavior the analysis was as shown in table 9.

\subsection{Table 9: Analysis of variance}

\begin{tabular}{|ll|r|r|r|r|r|}
\hline Model & Sum of Squares & Df & Mean Square & F & Sig. \\
\hline 1 & Regression & 15.058 & 25 & .602 & .946 & $.542^{\mathrm{b}}$ \\
& Residual & 170.061 & 267 & .637 & & \\
& Total & 185.119 & 292 & & & \\
\hline
\end{tabular}

Sum of squares- is the relationship of the total variance to the observations made and determines the dispersions of data points in a data set.

DF- the degree of freedom is the sum of individual DFs for each sample

F-the F-test is a ratio of two equal quantities expected to be generally equal in a null hypothesis. 
4.10 Table 10: Model Summary of Regression Analysis

\begin{tabular}{|l|r|r|r|r|r|}
\hline Model & \multicolumn{1}{|c|}{$\mathrm{R}$} & R Square & Adjusted R Square & Std. Error of the Estimate & \multicolumn{1}{c|}{ Durbin-Watson } \\
\hline 1 & $.320^{\mathrm{a}}$ & .103 & .019 & .685 & 1.915 \\
\hline
\end{tabular}

Adjusted R squared is the coefficient of determination which tells us the variation in the dependent variable due to changes in the independent variable.

$\mathrm{R}$ - The correlation coefficient which shows the relationship between the study variables.

$\mathrm{R}$ squared- the coefficient of multiple determination shows how statistical data is closely fitted to the regression line

There was a significant influence on the relationship between the variables time spent and ease of access to social media to one's consumer behavior.

\section{CONCLUSION}

The study encompassed respondents from all universities whether public, private, or mission that reside and operate in Nairobi county. The $80 \%$ response rate was very good to draw binding conclusions and resolutions as to how social media affects consumer behavior. The modes of accessing social media were varied and as such an organization should not dwell on one site to reach out to customers. There were other social media sites like google plus that were not listed in the questionnaire. A cumulative $97.1 \%$ spend between $0-9$ hours a day which is equivalent to $37.5 \%$ of their whole day. Credibility and authenticity of information posted on social media were key in influencing one to make or not make a purchase. An over 95\% cumulative percentage was found in both the decision-making stage like pre-purchase, purchase, and post-purchase. There were both external and internal stimuli that influenced consumers to make certain purchase decisions.

There was a positive correlation on social media influence on the consumer decision process. Social media was touted as an essential tool for information storage and search. Also peer reviews, families, friends, and pop up messages were essential to change of attitude towards a product. Product satisfaction or dissatisfaction was seen as feedback after consumption. If satisfied, one becomes a voluntary product ambassador else he negatively campaigns the entire product or brand. Other key factors were noted to be like accessibility and reliability of social media. The advent of smartphones, affordable cost of internet bundles, and credibility of posted product information was key to influencing decision making as opposed to traditional mass media. Without a doubt therefore, social media was found to have an enormous influence on consumption behavior amongst university students in Nairobi.

\section{IMPLICATIONS}

The positive correlation between the use of social media and consumer behavior implies that organizations should set aside social media departments and fulltime page administrators to engage their customers and prospects at all times. They can also profile their audience and provide specific products for specific segments in their different niches. However, there should be caution on the profiling since different groups of consumers prefer specific sites so they can engage on multiple sites instead. However, there is a need to regulate pop up messages, or block them as a whole from appearing on one's sites as they are majorly distasteful and annoying. The government can assist in the enactment of laws to have a conducive online environment for customer-producer interactions by treating such pops as trespass. The over $37.5 \%$ time spent on social media can be addressed in two-fold for instance it is a signal of idol workmanship that poses a greater danger now and in future and also seen an increasingly growing free market where organizations can tap and make use of. Both social media and consumer behavior are dynamic and as such more research needs to be done in this area.

\section{SUGGESTION FOR FURTHER RESEARCH}

This research should be subjected to further research. A study on specific social media sites can be done as opposed to focusing on all available sites. The sample frame should also be widened towards rural settings as opposed to Nairobi which is the biggest urban setting in Kenya. It can also focus on business entities as opposed to student consumers alone.

\section{REFERENCES}

Darban, A. and Li, W., 2012. The impact of online social networks on consumers' purchasing decision -The study of food retailers . Sweden. Journal of Management, Vol.5, No.1 (June, 2015). ISSN: 2229-0044

Boyd, D. and Ellison, N. 2007. Social network sites Definition, history, and Scholarship. Journal of ComputerMediated Communication, 13(1).

Campbell, M. C., and Goodstein, R. C. 2001. The moderating effect of perceived risk on consumers' evaluations of product incongruity: Preference for the norm. Journal of consumer Research, 28(3), pp. 439-449.

Chen, L. 2014. The influence of social media on consumer behavior: An empirical study on factors influencing 
consumer purchase . China.

CUE, C. f. 2016. State of university education. Nairobi.

Kaplan, A.M. and Heinlein, M. 2010. 'Users of the world, unite! The challenges and opportunities of Social Media', Business Horizons, 53, pp. 59-68

Kotler, P. and Keller, K. 2006. Marketing Management. Uppler Saddle River, New Jersey: Pearson Prentice Hall. Kotler, P. 1967. Marketing Management: Analysis, Forecasting, and Control.

Krejcie, R.V., and Morgan, D.W., 1970. Determining Sample Size for Research Activities. Educational and Psychological Measurement.

Mangold, W. and Faulds, D.J. 2009. The new hybrid element of the promotion mix. Business Horizons, 52(1), pp. 357-365.

Mugenda, O., and Mugenda, A. G. 2003. Research methods: Quantitative and Qualitative methods. Revised in Nairobi.

Mwaisaka, F. W. 2017. The Influence of Social Media on Consumer Decision making Process In The Cosmetic Industry In Nairobi County, Kenya. Nairobi, Kenya.

Mwangi, L. W. 2017. The Influence of social marketing on consumer behavior: a case of Nyeri Town constituency (Thesis). Strathmore University. Retrieved from http://suplus.strathmore.edu/handle/11071/5588

Oyetunde, J. O. 2017. Influence of Facebooking and Social Media Use on Academic Performance among Nigerian Undergraduate Social Sciences Students, South Africa.

Pather, M. 2014. Factors Affecting Consumer Decision Making Process in Africa: an exploratory studies. Pretoria, South Africa.

Schiffman, L. G., and Kanuk, L. L. 2004. Consumer Behavior, Printice-Hall International. Inc. USA, pp. 14-15.

Social, W. A. 2017. Hootsuite. 2018. Digital in.

Wang, H. 2012. Six p's of youth social media from a young consumer perspective.

Young Consumers, 13(3), pp. 303-317. 